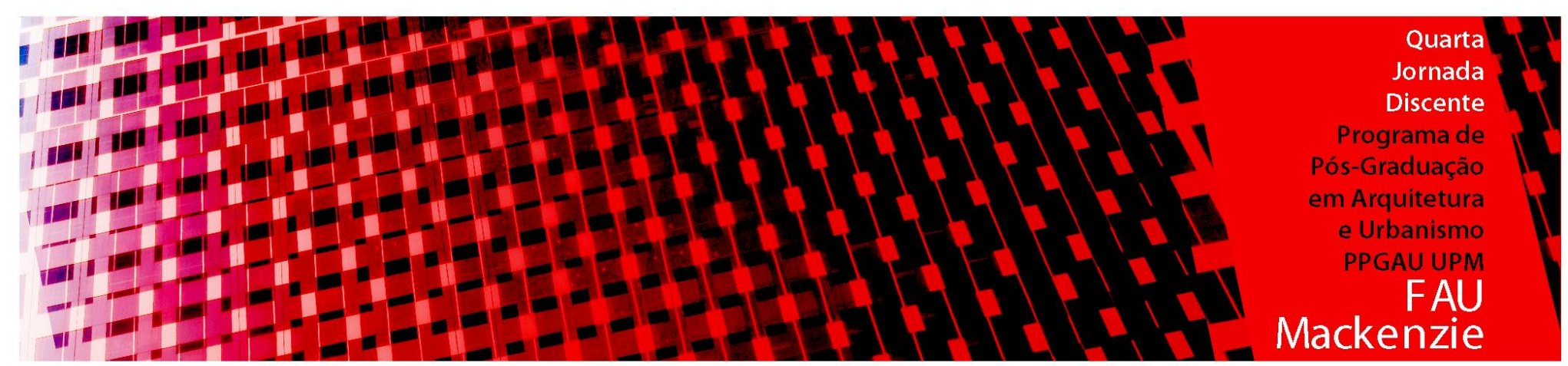

\title{
AS FRANJAS URBANO-AMBIENTAIS DA REGIÃO METROPOLITANA DE SÃO PAULO: ESTRATÉGIAS E BENEFÍCIOS
}

\section{THE URBAN-ENVIRONMENTAL FRINGES OF SÃO PAULO METROPOLITAN REGION: STRATEGIES AND BENEFITS}

\author{
Andresa Lêdo Marques', Angélica Benatti Alvim² \\ ${ }^{1}$ Universidade Presbiteriana Mackenzie, Rua Itambé, 45, Higienópolis, São Paulo-SP, Brasil. \\ andresa.ledo@hotmail.com \\ ${ }^{2}$ Universidade Presbiteriana Mackenzie, angelica.alvim@mackenzie.br
}




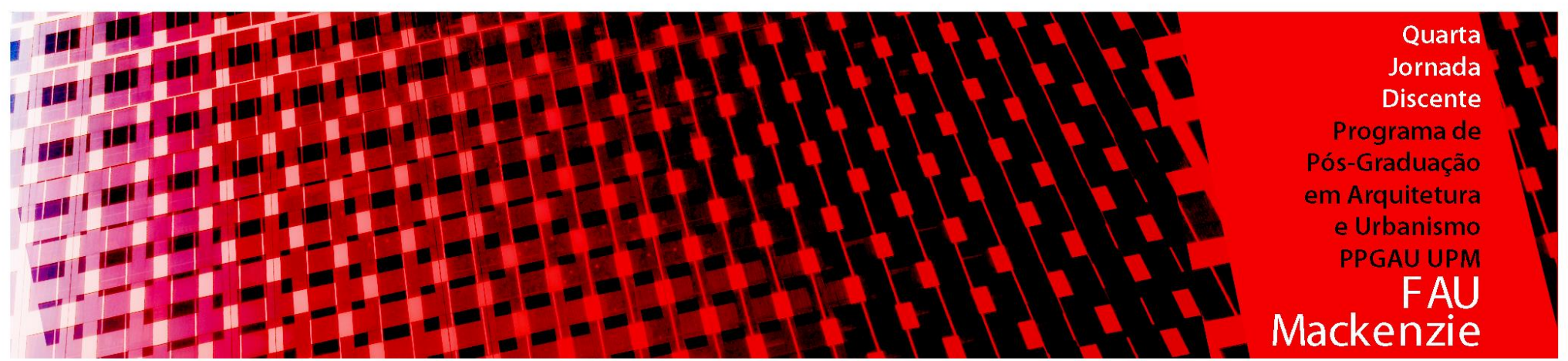

\title{
RESUMO
}

O presente artigo centra-se na discussão da importância ambiental das franjas metropolitanas da Região Metropolitana de São Paulo (RMSP), colocando em perspectiva a intensa urbanização que tem ocorrido nas franjas deste grande aglomerado urbano nos últimos anos, sobretudo nas bordas de seu território, em áreas de grande importância ecossistêmica. Estas franjas, aqui chamadas de franjas metropolitanas ou franjas urbano-ambientais, concentram importantes remanescentes naturais que são cruciais para a garantia da qualidade de vida de uma rede de municípios que formam a RMSP, como: Parques Estaduais, Áreas de Preservação Ambiental e Áreas de Mananciais. Busca-se discutir as interfaces entre assentamentos humanos, meio-ambiente, qualidade de vida e serviços ambientais. Para tanto, como parte da metodologia, foi realizada uma revisão bibliográfica do conceito de franja bem como a relevância ambiental das mesmas. Após a revisão da bibliografia, foi feita uma análise de dois estudos de caso de planejamento urbanoambiental de franjas metropolitanas, trazendo a discussão para o contexto da RMSP, evidenciando a importância da gestão sustentável dos recursos disponíveis nas franjas urbano-ambientais da metrópole paulista, bem como os inúmeros benefícios que estas podem oferecer em termos de qualidade de vida, gestão hídrica e infraestrutura à Região Metropolitana como um todo.

Palavras-chave: Franjas metropolitanas; franjas urbano-ambientais; Desenvolvimento urbano sustentável; Região Metropolitana de São Paulo; serviços ecossistêmicos.

\begin{abstract}
This article focuses on the environmental importance of the metropolitan fringes of the Metropolitan Region of São Paulo, putting in perspective the intense urbanization that has occurred in the fringes of this great urban agglomerate in the last years, especially in the borders of its territory, in areas of great ecosystemic importance. These fringes, here called metropolitan or urban-environmental fringes, concentrate important natural remnants that are crucial to guarantee the quality of life of a network of municipalities that form São Paulo Metropolitan Region, such as: State Parks, Preservation Areas and water springs. It seeks to discuss the interfaces between human settlements, environment, quality of life and environmental services. Therefore, as part of the methodology, a bibliographic review of the fringe concept was carried out, as well as the environmental relevance of the fringes. After reviewing the literature, an analysis of two case studies of urban and environmental planning metropolitan fringes was made, bringing the discussion to the context of the Metropolitan Region of São Paulo, highlighting the importance of sustainable management of available resources in the urban-environmental fringes of the metropolis of São Paulo, as well as the innumerable benefits that these can offer in terms quality of life, water management and infrastructure to the Metropolitan Region as a whole.
\end{abstract}

Key-words: Metropolitan fringes; urban-environmental fringes; Sustainable urban development; Sao Paulo Metropolitan Region; ecosystem services. 


\section{INTRODUÇÃO}

A questão da sustentabilidade tem ocupado um dos lugares centrais no que diz respeito à discussão do desenvolvimento do planeta, em todas as suas esferas. Dentro desta perspectiva, as cidades têm se destacado, pelo fato de na atualidade mais da metade da população mundial ter como seu habitat o ambiente urbano ${ }^{1}$. As cidades têm, por um lado, um papel fundamental no equilíbrio e sustentabilidade do planeta, pois, representam a oportunidade de uma maior qualidade de vida às pessoas, agregando instrumentos que proporcionam o uso e reaproveitamento sustentável dos recursos naturais, acesso a infraestrutura, mobilidade, entre outras vantagens que representa a vida urbana. Por outro lado, a intensidade do processo de urbanização no Brasil e no mundo têm exercido uma grande pressão sobre os serviços ambientais, estabelecendo um círculo vicioso da degradação ambiental associado a falta de planejamento urbano e gestão ambiental em muitas cidades (ALVIM; MARQUES; ALVES, 2018).

Carlos Leite (2012) afirma que as cidades são no momento o grande desafio estratégico para a sustentabilidade do planeta. Se as cidades adoecem, o planeta se torna insustentável. Nas palavras do autor:

O desenvolvimento sustentável é o maior desafio do século 21. A pauta da cidade é, no planeta urbano, da maior importância para todos os países, pois: (a) dois terços do consumo mundial de energia advém das cidades, (b) $75 \%$ dos resíduos são gerados nas cidades e vive-se um processo dramático de esgotamentos dos recursos hídricos e de consumo exagerado de água potável. A agenda Cidades Sustentáveis é, assim, desafio e oportunidade únicas no desenvolvimento das nações. (LEITE, 2012 p.8)

Além da questão do crescimento urbano populacional, existe também uma preocupação a respeito do estilo de vida que o modelo vigente de cidade tem trazido. Douglas Farr (2013) trabalha a ideia de que o modelo americano de cidade do século XX - modelo que influenciou fortemente o processo de urbanização das cidades brasileiras - tem uma parcela de responsabilidade no estilo de vida da população urbana, que de um modo geral possui pouco contato com a natureza. Segundo Farr (2013) o modelo vigente de cidade nos estimula cada vez mais a um estilo de vida individualista, que exerce a maioria de suas atividades em ambientes fechados, priorizando o uso do carro como meio de transporte, desestimulando assim o deslocamento a pé e o contato humano com o meio ambiente. $\mathrm{O}$ autor acredita que esse estilo de vida tem distanciado a população dos ciclos da natureza, tornando-a acostumada e "cega" frente aos danos que esse próprio estilo de vida tem causado.

Devido a essas questões de impacto das cidades na sustentabilidade do planeta, bem como no estilo de vida das pessoas, diversas instituições, organizações e mesmo tratados internacionalmente reconhecidos têm voltado sua atenção para a relevância das cidades no processo de transição para implementação de um desenvolvimento sustentável, ou seja, um conceito de desenvolvimento que surge a partir da tentativa de explorar alternativas ao modelo de desenvolvimento vigente e aos impactos que os seres humanos causam aos ambientes onde estes se inserem. No documento da ONU (Organização das Nações Unidas) "Transformando Nosso Mundo: A Agenda 2030 para o Desenvolvimento Sustentável” (2016) foram estabelecidos 17 objetivos de nível local e global para alcançar o desenvolvimento sustentável até 2030. Os objetivos propostos neste documento, em especial o objetivo 11 "Tornar as cidades inclusivas, seguras, resilientes e sustentáveis", reconhecem a relevância do desenvolvimento urbano como instrumento capaz de melhorar a qualidade de vida nas cidades e promover sustentabilidade (ALVIM, MARQUES; ALVES, 2018).

\footnotetext{
${ }^{1}$ Segundo relatório da ONU de 2018, chamado "World Urbanization Prospects", em 2018 55\% da população reside em áreas urbanas.
} 
Tendo em vista o atual contexto de crescimento urbano populacional e a importância das cidades no processo de transição para um modelo sustentável de desenvolvimento e aplicando essa discussão ao contexto da Região Metropolitana de São Paulo (RMSP), torna-se de extrema importância a discussão do papel das franjas metropolitanas e a promoção de estratégias de sustentabilidade para estas regiões.

Pesquisas recentes apontam que no contexto global, e de forma especial na América Latina e Caribe (ALC), o crescimento urbano populacional acelerado não vem ocorrendo com tanta intensidade nas cidades sedes das metrópoles, e sim nos centros menores de suas periferias. De acordo o IPEA (2015), estima-se que, em 2030, as pequenas e médias cidades representarão uma proporção ainda maior da população urbana. Os pequenos e médios centros urbanos serão responsáveis por $45 \%$ do aumento esperado na população urbana mundial entre 2009 e 2025, uma tendência que provavelmente continuará até 2030.

A RMSP configura um dos maiores aglomerados urbanos do mundo, chegando em 2017 a 21.391.624 de habitantes (IBGE, 2017 apud EMPLASA, 2018). As projeções ${ }^{2}$ populacionais apontam que este número tende a crescer ainda mais nos próximos anos, sobretudo nas franjas de seu território, em áreas que muitas vezes coincidem com áreas ambientalmente frágeis e relevantes. Esta região abriga a Bacia hidrográfica do Alto Tietê ${ }^{3}$, unidade de hídrica-ambiental que praticamente coincide com o território da região metropolitanas, correspondendo à área drenada pelo rio Tietê, desde sua nascente, no município de Salesópolis, até a montante da Barragem de Rasgão, em Santana do Parnaíba, envolvendo 34 municípios, dos 39 municípios da RMSP (CBHAT/FUSP, 2001); (ALVIM, 2003) .
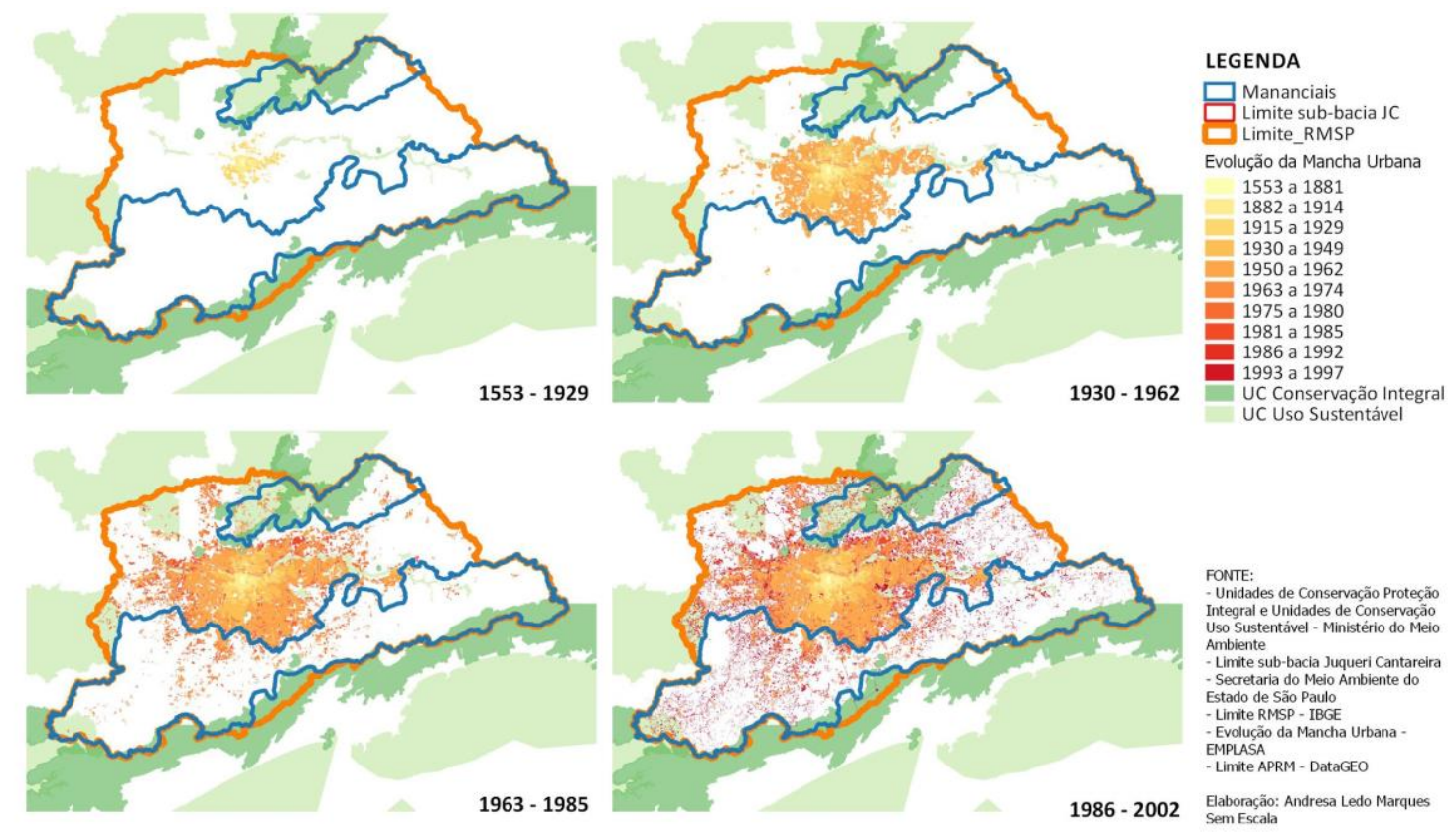

Figura 01 - Evolução da Mancha Urbana na Região Metropolitana de São Paulo versus Áreas Protegidas Fonte dos dados: Ministério do Meio Ambiente do Estado de São Paulo, IBGE e EMPLASA

Elaboração: Andresa Ledo Marques

\footnotetext{
${ }^{2}$ Projeções - Fundação SEADE. Informações dos Municípios Paulistas. Disponível em <http://www.imp.seade.gov.br/frontend/\#/tabelas>. Acesso em Junho de 2018.

3 A BAT abrange uma área de $5.985 \mathrm{~km}^{2}$ sendo composta pelas seguintes sub-bacias: Alto Tamanduateí; Billings; Cabeceiras; Cotia - Guarapiranga; Juqueri-Cantareira; Penha-Pinheiros; Pinheiros- Pirapora.

${ }^{4}$ No âmbito da política estadual de recursos hídricos, a bacia hidrográfica metropolitana corresponde à UGRHI Alto Tietê - ou UGRHI 06 (Lei Estadual n $7.633 / 91$ e incorpora 90 da população da \% da RMSP (ALVIM, 2003).
} 
A ocupação do espaço urbano deste território e o consequente espraiamento da mancha urbana são um dos principais impulsores da degradação ambiental e dos mananciais de água (Figura 01). Os assentamentos humanos deste grande aglomerado urbano, sobretudo os precários e localizados nas regiões periféricas, comprometem atualmente a sustentabilidade das áreas ambientalmente frágeis, seja pelo desmatamento, a degradação da fauna, do solo, ou das águas destinadas ao abastecimento público, tem agravado o quadro de depredação de áreas de grande importância ecossistêmica (ALVIM; MARQUES; ALVES, 2018).

Neste artigo, adotaremos o termo "franja metropolitana" ou "franjas urbano-ambientais" para discutir essas áreas periurbanas de grande importância ecossitêmica da Região Metropolitana de São Paulo.

\section{MÉTODO}

O presente artigo busca discutir as interfaces entre assentamentos humanos, meio-ambiente, qualidade de vida e serviços ambientais. Como parte da metodologia, com o intuito de atingir os objetivos propostos, foi realizada uma revisão bibliográfica do conceito de franja evidenciando a importância ambiental destes territórios que tem sido constantemente ameaçados pelas demandas de diversos atores. Depois desta etapa, foi explorado o conceito de sustentabilidade com ênfase na visão territorialista e do desenvolvimento local. Após a revisão da bibliografia, foi feita uma análise de dois estudos de caso de planejamento urbano-ambiental de franjas metropolitanas, a saber: o cinturão verde de Londres e o cinturão verde de Ottawa, trazendo a discussão para o contexto da Região Metropolitana de São Paulo, evidenciando a importância da gestão sustentável dos recursos disponíveis nas franjas urbano-ambientais da metrópole paulista, bem como os inúmeros benefícios que estas podem oferecer em termos de qualidade de vida, gestão hídrica e infraestrutura à uma rede de municípios que compõem a Região Metropolitana de São Paulo.

\section{FRANJAS METROPOLITANAS: DIMENSÕES URBANAS E AMBIENTAIS}

\subsection{CONCEITUANDO FRANJAS METROPOLITANAS}

As áreas periféricas da Região Metropolitana de São Paulo têm passado por um intenso processo de crescimento urbano populacional nos últimos anos. Estas áreas periféricas, estão em uma zona de transição entre dois grandes polos com usos mais definidos, sendo um polo densamente urbanizado e outro predominantemente rural (PRYOR, 1968, p.205), configurando territórios complexos e frequentemente pressionados por diversas demandas e atores. Estas zonas são denominadas franjas urbano-rurais ou áreas periurbanas. Robin Pryor (1968), um dos principais autores que se debruçou sobre o estudo das franjas urbano-rurais ${ }^{5}$ argumenta que estes territórios se configuram em uma zona de transição complexa na periferia das crescentes áreas urbanas nos países ocidentais. Nas palavras do autor:

A franja urbano-rural é uma zona de transição no uso do solo, com características sociais e demográficas, situando-se entre (a) as áreas urbanas e suburbanas continuamente construídas da cidade central, e (b) o interior rural, caracterizado pela quase completa

\footnotetext{
5 Definida pelos Anglo-Saxônicos como "rural-urban fringe" (ROCHA et al., 2005, p.5)
} 
ausência de habitações não agrícolas, ocupações e uso do solo, e de orientação social urbana e rural; um alcance incompleto e penetração de serviços de utilidade urbana; zoneamento desordenado ou regulamentos de planejamento; extensão areal além, embora contígua à fronteira política da cidade central; e um aumento real e potencial da densidade populacional, com a densidade atual acima dos distritos rurais circunvizinhos, mas inferior à da cidade central. Essas características podem diferir tanto de maneira zonal quanto setorial e serão modificadas ao longo do tempo (PRYOR, 1968 p. 206 - tradução nossa).

O conceito de franja é complexo e abordado de diferentes formas por pesquisadores do mundo todo. Alister James Scott (2013, p.9) ao fazer um panorama do conceito de franjas, adota o termo franja urbano-rural e aponta para como estas áreas têm sido vistas e conceituadas como: paisagens na borda, lugares de transição e do espraiamento urbano. $\mathrm{O}$ autor chama atenção para a quantidade de visões negativas acerca das franjas e argumenta que estes territórios estão muitas vezes inseridos em um limbo, à espera de planos, projetos e decisões, trazendo a reflexão sobre o caráter estratégico, sobretudo do ponto de vista ambiental, das franjas urbano-rurais.

Carter (1971 apud Rocha et al 2005) define a franja urbano-rural como um espaço pelo qual a cidade se expande num processo de dispersão e evolução da mancha urbana. A área é caracterizada por um conjunto de situações distintas, devido ao fato de que apenas parte do seu espaço foi assimilado pelo crescimento urbano, e uma parte ainda significativa possui características rurais. A figura 02, exemplifica bem as características desse transecto urbano-rural como essa zona de transição entre as áreas naturais ou rurais e os densos centros urbanizados (FARR, 2013, p. 21).

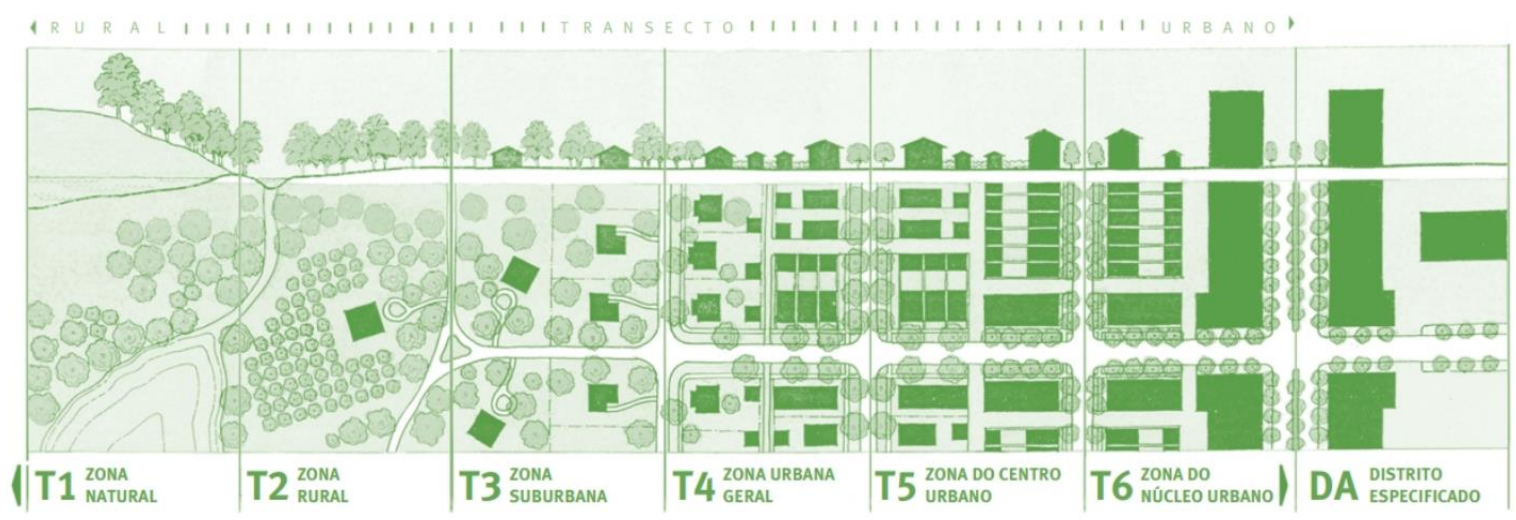

Figura 02 - O Transecto Urbano-Rural

Fonte: FARR, 2013, p. 21

As franjas possuem limites bastante imprecisos e uma variedade de usos que muitas vezes geram conflitos entre os diferentes atores envolvidos, evidenciando os valores econômicos, sociais, culturais e paisagísticos destas zonas de transição urbano-rural que apresenta uma grande variedade de usos (áreas de preservação ambiental, produção agropecuária, extração mineral e usos urbanos). De acordo com Scott (2013, p.9), existem dois enfoques diferentes que dividem a literatura internacional acerca das franjas com características urbanas e rurais: as franjas urbanorurais e as franjas rurais-urbanas. A primeira linha de raciocínio é mais focada na dimensão urbana, enxergando o território da franja como um espaço de transição para um conjunto cada vez maior de exigências centrados em questões da cidade como habitação, lazer, emprego e infraestrutura. Já a segunda linha de raciocínio é mais centrada nas questões rurais pensando nestes territórios como espaços potencialmente adequados a conservação e proteção ambiental como o plantio sustentável, plantio comunitário e plantação de florestas. 


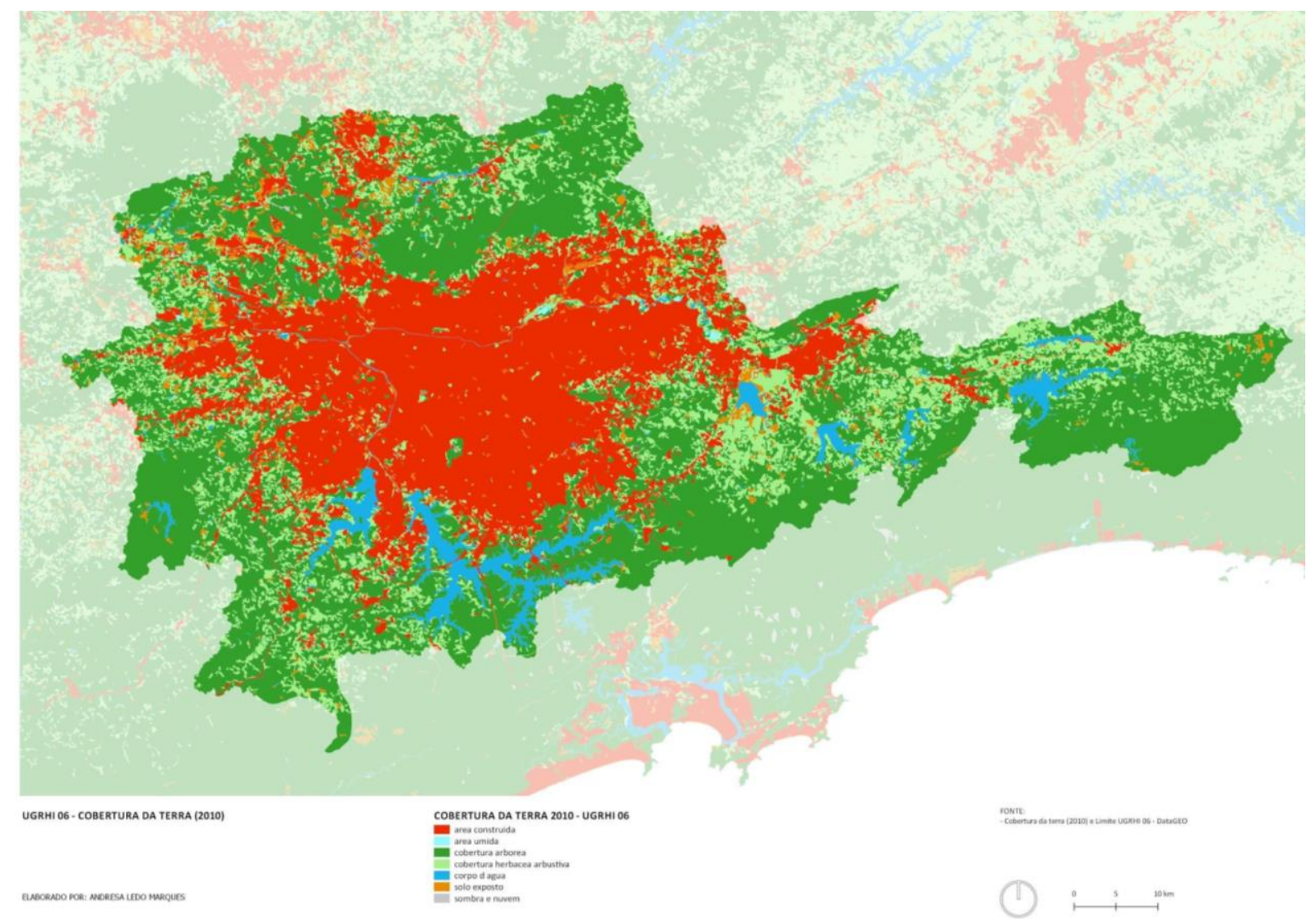

Figura 03 - Cobertura da Terra Bacia Alto Tietê (2010)

Fonte dos dados: DataGEO Elaboração: Andresa Ledo Marques

Trazendo essa discussão para o contexto brasileiro, mais especificamente para a região metropolitana de São Paulo, nota-se que as bordas da metrópole apresentam características bastante interessantes do ponto de vista ambiental, formando uma espécie de cinturão verde ao redor da densa mancha urbanizada que forma a capital, que coincide com parte da Reserva da Biosfera do Cinturão Verde da Cidade de São Paulo ${ }^{6}$. (Figuras 03)

A Reserva da Biosfera do Cinturão Verde da Cidade de São Paulo - RBCV abrange integralmente a Região Metropolitana de São Paulo e Baixada Santista e, parcialmente, as Regiões Administrativas de Campinas, Registro, São José dos Campos e Sorocaba, abrigando importantes serviços ecossistêmicos, como recursos hídricos, florestais, gêneros agrícolas, controle de desastres naturais, aspectos culturais, etc. Por sua vez, estes serviços estão vinculados ao cotidiano metropolitano e são influenciados por vetores diretos e indiretos de alteração ambiental, gerados pelo mesmo aglomerado urbano (RODRIGUES et al, 2006, p. 72).

As características dessa grande área periurbana vão de encontro ao conceito de franjas urbanorurais, discutidas até então. É importante retomar aqui o conceito de rural, posto que muitas vezes tal conceito só é utilizado ou atribuído a zonas de produção agropecuária. No entanto, uma zona rural pode ser entendida como uma região não urbanizada, de baixa densidade habitacional, com

\footnotetext{
${ }^{6}$ Criadas pelo Programa o Homem e a Biosfera - MAB (Man and Biosphere), da Organização das Nações Unidas (ONU) para a Educação, a Ciência e Cultura da Unesco
} 
áreas destinadas a agricultura e pecuária, turismo rural ou mesmo conservação ambiental. (IBGE, 2017)

Segundo estudo realizado pelo IBGE em 2017, denominado "Classificação e caracterização dos espaços rurais e urbanos no Brasil: uma primeira aproximação", as áreas rurais e urbanas não são facilmente identificáveis, sobretudo devido a grande interligação que tem ocorrido entre as mesmas no contexto brasileiro. O decreto-lei 311/38, que dispõe sobre a divisão territorial do país, estipula que a delimitação de zonas rurais e urbanas é de responsabilidade do município, no entanto, o decreto não estabelece diretrizes ou parâmetros que ofereçam suporte para caracterização de áreas rurais, apenas para as urbanas. No caso brasileiro, o município deve definir seus limites urbanos - conforme os parâmetros estabelecidos pelo decreto-lei 311/38 - e toda a área externa a esse perímetro é caracterizada como rural (IBGE, 2017, p.38).

Nessa perspectiva, considerando o crescimento da população nos limites urbanos dos municípios em questão e a grande relevância ambiental que a região apresenta, considera-se mais prudente fazer uso do termo franjas urbano-ambientais ou franjas metropolitanas para discutir a região em questão, posto que a dimensão ambiental se destaca como a grande vocação deste território e o termo rural, no contexto brasileiro, é muitas vezes compreendido como uma zona de produção agropecuária, que não se configura na principal atividade da região de estudo, por mais que a mesma apresente áreas potencialmente adequadas a pequena produção de alimentos. Portanto, na discussão apresentada aqui, serão utilizados os termos: franjas urbano-ambientais ou franjas metropolitanas.

\section{A IMPORTÂNCIA DOS SERVIÇOS AMBIENTAIS DESEMPENHADOS PELAS FRANJAS URBANO-AMBIENTAIS}

Considerando a vocação ambiental das franjas da Região Metropolitana de São Paulo é importante destacar alguns dos serviços ambientais e ecossistêmicos prestados pela mesma. Ao redor da grande mancha urbanizada da cidade de São Paulo está uma espécie de cinturão verde, que vem sido intensamente ameaçado pelo processo de urbanização espraiada. Este cinturão, como já mencionado anteriormente, coincide em parte com a Reserva da Biosfera do Cinturão Verde da Cidade de São Paulo. Uma pesquisa realizada em 2006 reuniu uma série de indicadores qualitativos que demonstram os principais serviços ambientais prestados por este território, que estão ilustrados no quadro a seguir.

Nessa mesma perspectiva de serviços ecossistêmicos, Quevedo Neto e Lombardo (2005) acreditam que as franjas desempenham um papel muito importante nas grandes cidades. Segundo os autores, estas áreas representam uma porção importante da cidade, não apenas do ponto de vista ambiental, pelos serviços ecológicos que presta à população, mas também como espaços de tranquilidade e segurança, de contato com a natureza, funcionando como espaços de refúgio frente às pressões das grandes cidades, sendo utilizadas como áreas de lazer e recreação para a população. No entanto, apesar da importância e benefícios ambientais da área em questão, as pressões exercidas pelo processo de espraiamento e crescimento urbano populacional discutidos na primeira parte do presente capítulo acabam gerando um ciclo de degradação intenso. Nessa perspectiva, as franjas das grandes metrópoles se transformam em territórios nos quais a dimensão ambiental e os elementos naturais são intensamente ameaçados pelos processos de ocupação urbana, processos estes que muitas vezes desconsideram as condicionantes naturais preexistentes e prejudicam as dinâmicas e funções ambientais ${ }^{7}$ desempenhados por importantes remanescentes naturais (LEITE, 2017; DORADO,2018).

\footnotetext{
${ }^{7}$ De acordo com Alexandre Dorado (2018, p. 542) os serviços ambientais podem ser de provisão (produtos extraídos diretamente do ambiente, como sementes, água, combustível e etc), de controle (qualidade da água, polinização, qualidade do solo e etc) e os culturais (benefícios imateriais, como: lazer, espiritualidade e etc).
} 
Para garantir a conservação da biodiversidade em territórios de vocação ambiental que tem passado por intensas transformações em sua paisagem e uso do solo, é preciso pensar em estratégias que mantenham a conectividade necessárias entre as espécies, garantam a manutenção dos processos ecológicos nas cidades e contribuam para a qualidade de vida da população que vive no meio urbano. A ação humana promovendo o desmatamento e impermeabilização do solo para implantação de diversas atividades urbanas contribuem para o agravamento e aumento das áreas de enchentes, erosão do solo e poluição atmosférica e hídrica. Estas ações alteram o ciclo natural da água, dificultando o retorno da água aos lençóis freáticos, o assoreamento dos rios, a erosão e a formação de ilhas de calor nas cidades (HOUGH, 2004; PELLEGRINO; GUEDES; FERNANDES, 2006).

Quadro 1: Síntese dos Principais Serviços Ambientais Associados à Reserva da Biosfera do Cinturão Verde -

RBCV

\begin{tabular}{|c|c|}
\hline Serviço Ambiental & Descrição e Importância do Serviço Ambiental \\
\hline \multicolumn{2}{|r|}{ SERVIÇOS DE SUPORTE } \\
\hline $\begin{array}{l}\text { Manutenção dos } \\
\text { processos ecológicos e da } \\
\text { biodiversidade }\end{array}$ & $\begin{array}{l}\text { A Mata Atlântica é um dos biomas mais biodiversos do planeta. A manutenção de sua riqueza } \\
\text { biológica é dever ético da população e resguardo, sob vários pontos de vista, do próprio bem-estar do } \\
\text { ser humano. Localmente, as matas do Cinturão Verde configuram-se como importantes corredores } \\
\text { ecológicos, verdadeiros elos entre diferentes áreas florestais do Brasil. Dentro dessa categoria, os } \\
\text { ecossistemas determinam serviços como formação dos solos, ciclagem de nutrientes, produção } \\
\text { primária, polinização, resiliência, etc. }\end{array}$ \\
\hline \multicolumn{2}{|r|}{ SERVIÇOS DE PROVISÃO } \\
\hline $\begin{array}{l}\text { Conservação e oferta } \\
\text { de água (superficial e } \\
\text { subterrânea) }\end{array}$ & $\begin{array}{l}\text { Os recursos hídricos abrigados pelo Cinturão Verde abastecem mais de } 20 \text { milhões de pessoas. } \\
\text { Seu comprometimento pode gerar um colapso no abastecimento público, cuja escassez já é sentida } \\
\text { nas épocas mais secas do ano. Existe também grande correlação entre preservação de florestas e } \\
\text { qualidade da água, com fortes implicações econômicas. }\end{array}$ \\
\hline $\begin{array}{l}\text { Oferta de princípios ativos } \\
\text { e recursos genéticos }\end{array}$ & $\begin{array}{l}\text { A Mata Atlântica é uma reserva para descobertas em benefício do homem, como a produção de } \\
\text { fármacos e substâncias de valor econômico. }\end{array}$ \\
\hline Segurança alimentar & $\begin{array}{l}\text { Atualmente, } 15 \% \text { do alimento do mundo é produzido em quintais e pequenos terrenos (lan Douglas, } \\
\text { Universidade de Manchester, } 2002 \text {, informação pessoal). } 0 \text { Cinturão Verde tem essa vocação e hoje } \\
\text { é uma das principais regiôes de produção orgânica do país. Além disso, a opção agrícola em regiôes } \\
\text { periurbanas é vista como alternativa ao inchaço das grandes cidades. }\end{array}$ \\
\hline $\begin{array}{l}\text { Recursos florestais } \\
\text { madeireiros e não- } \\
\text { madeireiros }\end{array}$ & $\begin{array}{l}\text { A matéria-prima florestal produzida no Cinturão Verde é representativa na economia de base florestal } \\
\text { do Estado de São Paulo, principalmente em função dos reflorestamentos. As florestas naturais } \\
\text { também fornecem recursos importantes para diversas comunidades no âmbito do Cinturão, e o } \\
\text { desenvolvimento técnico-científico, aliado à implementação de políticas públicas saudáveis, pode } \\
\text { incrementar a participação dessas florestas no aporte de recursos importantes à economia e ao bem- } \\
\text { estar da população. }\end{array}$ \\
\hline \multicolumn{2}{|r|}{ SERVIÇOS DE REGULAÇÃO } \\
\hline Regulação climática & $\begin{array}{l}0 \text { Cinturão Verde tem relação direta com amenização climática da região, em contraponto as áreas } \\
\text { densamente antropizadas, que geram aumento de temperatura (ilhas de calor). Esse fenômeno tem } \\
\text { apresentado encadeamentos que extrapolam a questão do conforto térmico e passa a interferir em } \\
\text { regime pluviométrico, com grandes enchentes na região urbana. }\end{array}$ \\
\hline $\begin{array}{l}\text { Seqüestro de } \mathrm{CO}_{2} \text { e } \\
\text { redução de poluentes }\end{array}$ & $\begin{array}{l}0 \text { Cinturão Verde tem } 311.407 \text { hectares de vegetação secundária e } 120.000 \text { hectares de } \\
\text { reflorestamentos, vegetações em crescimento com importante papel no seqüestro do } \mathrm{CO}_{2} \text { gerado pela } \\
\text { metrópole; complementarmente, as florestas representam importante barreira fisica para } 0 \text { avanço de } \\
\text { poluentes produzidos nas metrópoles. Tudo isso implica em impactos globais e locais, inclusive de } \\
\text { saúde pública. }\end{array}$ \\
\hline $\begin{array}{l}\text { Conservação do solo e } \\
\text { controle de enchentes }\end{array}$ & $\begin{array}{l}\text { Combate à erosão de solo, estabilização de áreas sensiveis, manutenção da permeabilidade do solo, } \\
\text { minimização de enchentes e calamidades públicas. }\end{array}$ \\
\hline \multicolumn{2}{|r|}{ SERVIÇOS CULTURAIS } \\
\hline Lazer, recreação, estética & $\begin{array}{l}\text { As metrópoles de São Paulo e Santos são pobres em áreas verdes. As áreas envoltórias dessas urbes, } \\
\text { representadas pelo Cinturão Verde, em muitas situações, constituem importantes alternativas para que } \\
\text { a população mantenha contato com o meio natural. Isso é fundamental para a humanização e a saúde } \\
\text { física e psíquica da população. Igualmente, o padrão estético da região, determinado pelas florestas, } \\
\text { áreas silvestres, mar, mangue, praias, áreas rurais, é um patrimônio de valor inestimável, com reflexos } \\
\text { na economia, no bem-estar e no pertencimento da população. }\end{array}$ \\
\hline $\begin{array}{l}\text { Abrigo da história e do } \\
\text { patrimônio cultural }\end{array}$ & $\begin{array}{l}0 \text { Cinturão Verde testemunhou passagens importantes da história do Brasil antes e depois de sua } \\
\text { descoberta, e abriga vestígios dessa memória popular, perpetuando-a. }\end{array}$ \\
\hline Turismo sustentável & $\begin{array}{l}\text { As áreas integrantes do Cinturão Verde guardam enorme potencial para a prática do turismo } \\
\text { sustentável em várias de suas modalidades, incrementando o rol das iniciativas para o } \\
\text { desenvolvimento sustentável e a geração de renda de vários setores e comunidades. }\end{array}$ \\
\hline
\end{tabular}

Fonte: RBCV (2003) apud RODRIGUES et al, 2006 
Apesar dos ambientes urbanos ou suburbanos e a biodiversidade ainda serem vistos como mutuamente exclusivos, alguns trabalhos de planejamento urbano mais recentes reconhecem os serviços ecológicos que a manutenção da biodiversidade no ambiente urbano pode trazer tanto para uma maior sustentabilidade dos fragmentos remanescentes no interior das zonas urbanizadas, como para áreas naturais em suas áreas de influência (HELLMUND \& SMITH, 1993). Nestes trabalhos, as áreas de vegetação em sítios urbanos são vistas como grandes desafios de manejo para os planejadores preocupados com a biodiversidade, e não apenas como terrenos baldios biologicamente pouco significativos, de pouca importância sócio-econômica ou meramente justificados para o lazer humano (PELLEGRINO; GUEDES; FERNANDES, 2006, p.4).

As franjas metropolitanas ou franjas urbano-ambientais, configuram um território em potencial para se tornar objeto de planejamento ecológico da paisagem, como uma infraestrutura verde, sendo tratados como patrimônio natural, cultural e econômico. As áreas verdes e florestas regulam os ciclos hidrológicos, protegem o solo, os cursos d'água, evitam a erosão, melhoram a qualidade da água e do ar e proporcionam ambientes agradáveis aos seres humanos (HOUGH, 2004). Nesse sentido, o desenho e o planejamento destas áreas devem trabalhar a possibilidade de valorização, o resgate cultural e ambiental do local, bem como a preservação dos ecossistemas naturais remanescentes. Os benefícios de uma boa gestão destas áreas estratégicas são inúmeros tanto na perspectiva social, quanto ambiental (LEITE, 2017; PELLEGRINO; GUEDES; FERNANDES, 2006 ; HOUGH, 2004;). Nas palavras de Pellegrino:

A fundamentação conceitual da infraestrutura verde começa com a água e o ciclo hidrológico; seguida pelo microclima e consumo de energia; vegetação urbana, ecologia da paisagem, biodiversidade e fragmentação de habitats; e, finalmente, pelo uso social, circulação e apropriação dos espaços urbanos pela população (PELLEGRINO,2017, p.64).

Todos os aspectos elencados acima demonstram a importância, sobretudo ambiental, das zonas de transição entre o rural e o urbano, as franjas metropolitanas ou franjas urbano-ambientais. Estas áreas configuram territórios de grande importância ambiental para a garantia do equilíbrio ecossistêmico da metrópole como um todo, garantindo a conservação da biodiversidade, a qualidade da água e a continuidade dos processos ecológicos nas cidades.

\section{UM OLHAR SOBRE O TERRITÓRIO: ENTRE O URBANO E O AMBIENTAL}

O construído e o natural têm sido vistos de maneira bastante antagônica. Em relação a gestão sustentável dos recursos de um território brasileiro, acentuou-se no final dos anos 60 um certo antagonismo entre desenvolvimento econômico e ecologia. De um lado estava a visão ecologista, na qual acreditava-se que a questão econômica estava agredindo o meio ambiente brasileiro. Do outro lado, estava a visão econômica, que enxergava que questão ecológica estava dificultando o desenvolvimento do país, criando um falso antagonismo entre as dimensões ambiental e econômica (PHILIPPI;ROMÉRO;BRUNA, 2014, p.665). Em oposição a uma visão antagônica, muitos autores defendem que o desenvolvimento econômico deve ser promovido buscando sempre a promoção da melhoria da qualidade do meio ambiente, sem comprometer os recursos naturais, e vice-versa. O objetivo de ambos deve ser o bem-estar, evolução, qualidade ambiental e de vida dos seres vivos.

Acselrad (2004), Bellen (2006), Farr (2013) e Magnaghi (2005) discutem que o conceito de desenvolvimento sustentável surge em resposta a crise dos conceitos tradicionais de crescimento e desenvolvimento. A partir dessa discussão, surgiram algumas linhas principais de pensamento que conceituam o desenvolvimento sustentável, algumas mais tecnocêntricas, outras mais 
ecocêntricas. Bellen (2006, p.26), propõe um quadro ${ }^{8}$ ilustrando as nuances entre estes dois extremos ideológicos e suas particularidades.

Quadro 2: Dimensões do ambientalismo

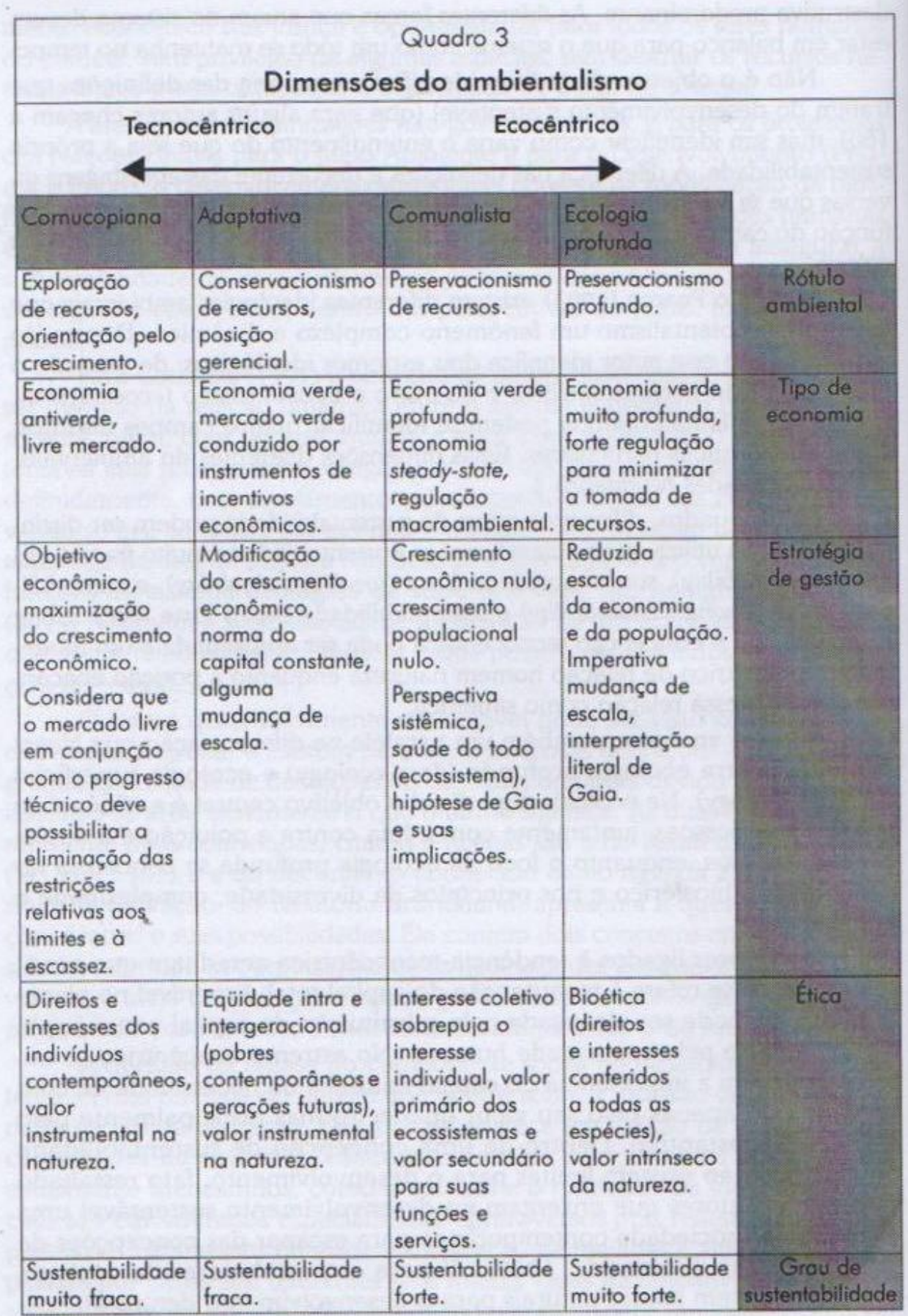

Fonte: adaptado de Pearce (1993).

Fonte: Bellen (2006, p.26) adaptado de Pearce (1993)

\footnotetext{
${ }^{8}$ O quadro montado por Hans Michael van Bellen foi montado a partir da discussão de Pearce no livro "Environmental economics" de 1993.
} 
Magnaghi (2005, p. 83), divide as linhas de compreensão do conceito de sustentabilidade em três grupos com enfoques distintos:

O enfoque funcionalista, que propõe uma espécie de modernização ecológica;

O enfoque ambientalista, que é biocêntrico, ou seja, centrado na natureza;

O enfoque territorialista, que é antrobiocêntrico, ou seja, centrado no homem e na natureza;

Segundo o autor, a visão funcionalista apresenta uma estratégia mais "corretora", a ciência e a tecnologia são vistas como a solução dos problemas ambientais por meio de soluções padronizadas propondo proibições, medidas e legislações que mitigam os efeitos da degradação ambiental e estabelece a capacidade de carga/usos que uma determinada área pode suportar, tratando o território como um suporte técnico-funcional da produção no qual as leis de mercado global decidem como as atividades serão implantadas no território, sem destruir o local em que as mesmas se desenvolvem, não levando em consideração que cada território possui características culturais, uma identidade, memória, linguagem, bem como mensagens simbólicas e afetivas (MAGNAGHI, 2005, p. 84).

A grande crítica de Magnaghi ao enfoque funcionalista é o fato de o mesmo não questionar a primazia da dimensão econômica, sem considerar que alguns danos ou mesmo serviços ambientais são imensuráveis, e portanto não "reembolsáveis". Na perspectiva do autor, essa visão mais econômica e corretora não foi capaz de neutralizar a reprodução dos fatores de degradação ambiental e acabou incentivando projetos que, muitas vezes, reduzem a complexidade dos ecossistemas e os artificializam, além de produzir uma certa injustiça ambiental, transferindo as consequências dos desequilíbrios ecossistêmicos para países e comunidades mais pobres (MAGNAGHI, 2005, p. 84; ACSELRAD, 2004, p.29).

Ainda segundo Magnaghi, o enfoque ambientalista entende o meio ambiente como um sistema natural com leis próprias que devem ser respeitas. Nesse sentido a interação entre o ambiente natural e construído, passa a ser vista como um problema. No enfoque ambientalista a economia deve ser reestruturada, tendo como base a "economia da natureza", inserindo o "capital natural" entre o capital produzido pelas pessoas e aquele pelo trabalho, propondo assim uma espécie de "economia ecológica". Na tentativa de defender a dimensão ambiental, tão degradada por modelos de desenvolvimento baseados na priorização do crescimento econômico, a visão ambientalista não define limites à poluição e degradação, mas tem como base sistemas de alta qualidade ambiental e ecoeficiência (MAGNAGHI, 2005, p. 88).

Apesar de o modelo ambientalista assumir uma visão crítica e contrária ao modelo de desenvolvimento baseado no crescimento econômico ilimitado, e propor um novo paradigma de desenvolvimento, a abordagem ambientalista tende direcionar suas ações a salvaguarda da natureza, podendo muitas vezes tender a um determinismo rígido do desenho do ambiente antrópico e, por outro, de não reproduzir uma crítica radical do sistema socioeconômico que determina a degradação ambiental (MAGNAGHI, 2005, p. 88; DORADO, 2018, p.544).

$\mathrm{O}$ terceiro enfoque trabalhado por Magnaghi é o territorialista. Assim como a abordagem ambientalista, ela também interpreta o território como uma mistura de ecossistemas, em direção a uma visão ecossistêmica integrada. Porém, a grande diferença entre as duas visões está na centralidade das mesmas, o territorialismo enfrenta a questão da sustentabilidade centrando sua atenção no ambiente humano (ambiente natural, ambiente construído e ambiente antrópico), pensando no desenvolvimento sustentável a partir do território, entendido como um neoecossistema produzido por pessoas, incluindo as relações entre cultura, natureza e história. A partir desta perspectiva holística, a degradação do território, implica consequentemente em uma degradação do território natural, construído e da degradação social. (MAGNAGHI, 2005, p. 92) A abordagem territorialista supera a visão dualista que divide o território entre as áreas com função "econômica" e as áreas protegidas, com função "naturalista", em direção a uma visão sistêmica e integrada, em que todo o território (incluindo o ambiente urbano) é tratado como um neo- 
ecossistema, buscando um conceito de sustentabilidade ambiental, social, territorial, econômico e político. Nas palavras do autor:

A abordagem territorialista interpreta, portanto, a degradação ambiental (e a insustentabilidade do modelo de desenvolvimento que a produz) como consequência do processo sistemático de desterritorialização e destruição das relações sinérgicas entre o ambiente físico, construído e antrópico que caracteriza o modelo da ocupação contemporânea. Essa abordagem busca, portanto, a solução do problema da sustentabilidade na promoção de ações territorializantes que reconstituam, de forma inovadora, essas relações (MAGNAGHI, 2005, p. 94 - tradução nossa).

A concepção de gestão ambiental e sustentabilidade trabalhada nesta pesquisa alinha-se a perspectiva territorialista discutida por Magnaghi, tendo em vista o equilíbrio entre o homem e o seu ambiente, seja natural ou urbano, buscando um desenvolvimento sustentável, que implica no desenvolvimento dentro dos padrões de respeito à natureza englobados em três tipos de valores: os não-tangíveis (éticos, estéticos, culturais, recreativos, científicos e educativos), os valores ecológicos e os valores econômicos (PHILIPPI, ROMÉRO E BRUNA, 2014, p.666).

De acordo com Philippi, Roméro e Bruna (2014, p.696), as necessidades emergentes e a busca por soluções ao modelo de desenvolvimento vigente exigem uma visão integrada, holística e sistêmica. Quando se trata de meio ambiente todas as partes mantém inter-relações, um vínculo vital entre si. Não cabe uma análise cartesiana. É importante ressaltar que meio ambiente, abrange tanto o meio natural como o construído. Gestão ambiental envolve planejamento territorial. Trata-se de dirigir ecossistemas naturais ou sociais em que se insere o homem, individual e socialmente.

Considerando que vivemos em um planeta urbano, tomando como pressuposto que o crescimento urbano populacional é uma tendência para os próximos anos e tendo em vista a importância ambiental das franjas metropolitanas trabalhadas na presente pesquisa, assume-se que o planejamento urbano deve estar articulado ao planejamento e gestão ambiental, para que exista uma harmonia entre o ambiente natural e o ambiente construído. É preciso considerar também o fato de que o meio ambiente (natural ou construído) está em constante transformação, portanto, a gestão ambiental eficiente corresponde a existência e utilização de um conjunto de instrumentos, enquanto a gestão eficaz passa a existir quando esse conjunto de instrumentos se transformam em ações que se traduzem em problemas resolvidos.

\section{DESENVOLVIMENTO AUTO-SUSTENTÁVEL LOCAL: RISCOS, VULNERABILIDADES E RESILIÊNCIA}

Tendo em vista uma abordagem integrada e sistêmica do território e considerando o enfoque territorialista no contex to das franjas urbano-ambientais da Região Metropolitana de São Paulo, é preciso considerar que o intenso processo de urbanização neste cenário, tem trazido uma alteração da paisagem local, bem como da sua diversidade biológica, colocando em risco a qualidade ambiental da metrópole como um todo.

Paulo Saldiva (2018) e Alberto Magnaghi (2005) propõem um paralelo entre a biologia e a cidade. Magnaghi aborda o território como um ser vivo que possui um ciclo de vida, características próprias, personalidade e identidade. Ao construir um ambiente artificial, o urbano, nossa civilização tem gradualmente se distanciado de uma relação mais consciente com meio ambiente, estabelecendo suas relações de trabalho, lazer e mobilidade em ambientes fechados e/ou artificiais, e vivendo um estilo de vida que potencializa a poluição e o desperdício, em diferentes aspectos. Pensando no caso dos grandes aglomerados urbanos, como as metrópoles contemporâneas, podese dizer que apesar dos muitos aspectos positivos que acompanharam o avanço e o crescimento 
dessas grandes cidades, tem havido uma gradual diminuição da qualidade de vida nesses ambientes, sobretudo devido ao próprio estilo de vida adotado nestas cidades (FARR, 2013; MAGNAGHI, 2005; SALDIVA, 2018).

De acordo Alberto Magnaghi (2005) e Douglas Faar (2013), o estilo de vida e a forma de produção das cidades com uma tendência a usar os recursos humanos, ambientais e territoriais de forma predatória tem causado uma enorme degradação ambiental. Paulo Saldiva (2018) complementa essa argumentação, trazendo a perspectiva da saúde pública, elencando algumas condições urbanas que propiciam o adoecimento da população, como: a poluição atmosférica, as ilhas de calor, alterações do ciclo hidrológico, imobilidade, violência, a falta de contato com a natureza e etc. Infelizmente, muitas cidades proporcionam um distanciamento da população urbana dos ciclos da natureza, e também um certo descompasso em relação às consequências dos desequilíbrios ambientais, que muitas vezes são mais perceptíveis e apresentam consequências mais graves em territórios periféricos e precários do que em bairros mais centrais, dotados de infraestrutura (ACSELRAD, 2004).

Quando o território e seu patrimônio ambiental e cultural são considerados no desenho urbano, a resiliência, a consciência ambiental, patrimonial e cultural aumenta substancialmente pois, há um consequente aumento do contato da população com o lugar que habitam, colocando os habitantes em contato com a história e os ciclos naturais do território em questão. Este maior contato proporciona uma proximidade aos danos que o próprio estilo de vida da comunidade tem trazido para o ambiente local, bem como a importância das decisões de setores públicos e privados e seus desdobramentos no contexto local (MAGNAGHI, 2005; HOUGH, 2004).

Diversos autores (MAGNAGHI, 2005; FAAR, 2013; ACSELRAD, 2004; SALDIVA, 2018) discorrem acerca do crescimento de movimentos sociais e linhas de pesquisa, no Brasil e no mundo, que buscam encontrar caminhos para regeneração do território, trazendo uma perspectiva de desenvolvimento sustentável do planeta,de uma relação saudável entre os assentamentos humanos e o meio ambiente, em uma perspectiva de desenvolvimento que está apoiada no desenvolvimento local, denominada por Magnaghi (2005) como "auto-desenvolvimento sustentável local". Tal conceito visa explorar maneiras de se reestabelecer uma relação harmoniosa entre natureza e cultura, e cultura e história.

Em um contexto no qual as florestas e os rios fazem parte do cotidianos das pessoas, sendo reconhecidas como patrimônio cultural e natural, e evidenciando os elementos que sustentam a vida humana, a degradação destes patrimônios (invasões, queimadas, desmatamento, poluição) passa a ser vista como uma ameaça à população (HOUGH, 2004).

\section{ESTRATÉGIAS DE PLANEJAMENTO DAS FRANJAS METROPOLITANAS: O CINTURÃO VERDE METROPOLITANO DE LONDRES E OTTAWA}

A cidade de Londres apresentou um intenso crescimento urbano populacional no século XIX. Este crescimento desencadeou uma série de problemas de caráter urbano na cidade. Além dos problemas urbanos, havia também alguns problemas de governança no contexto londrino pois, a cidade não tinha uma governança central. Ainda no século XIX, mais precisamente em 1855, foi criada a Agência Metropolitana de Obras em Londres, que era responsável pelas obras de toda metrópole londrina e contava com gestores eleitos por agências locais. Depois disso, em 1889, foi criado o Condado de Londres (London County Council - LCC) para a cidade fosse considerada um conselho administrativo e não precisasse mais estar subordinado a condados compostos por cidades maiores (LUCCHESE, 2012).

O Plano do Condado de Londres foi realizado em 1943 e foi coordenado por J. H. Forshaw, arquiteto-chefe do conselho assessorado por Patrick Abercrombie. Na ocasião, ainda não existia a Greater London (Região Metropolitana de Londres), que foi criada dois anos depois, em 1945. A 
elaboração do plano ocorreu durante a guerra e teve influência dos princípios de cidade-jardim de Ebenezer Howard. O objetivo do plano era a proposição de uma agenda pós guerra para o Condado de Londres, o plano estabeleceu que a grande mancha urbana do londrina fosse circundada por um cinturão verde, criou um sistemas de áreas verdes, praças e parques em todo o Condado, reforçou os limites dos bairros espraiados e suas identidades, alterou e reconstruiu o tecido urbano em alguns pontos - sobretudo de áreas destruídas na guerra - e determinou a localização das novas habitações a serem implantadas. (HOUGH, 2004; LUCCHESE, 2012)

No contexto britânico, a questão dos cinturões verdes tem ocupado um lugar central na discussão e proposição de políticas públicas desde os anos de 1960, compondo na Inglaterra um total de 14 cinturões verdes ao redor de áreas urbanizadas. Ainda considerando o contexto britânico, desde o início dos anos de 1990 o conceito dos cinturões verdes passou a ser ainda mais reforçado tendo em vista um compromisso com o desenvolvimento urbano sustentável, garantindo a preservação ambiental e evitando o espraiamento da cidade (HOUGH, 2004).

Os cinturões verdes têm várias finalidades: proteger bacias hidrográficas, lençóis freáticos, aqüíferos e outros componentes biofísicos da paisagem; proteger o campo e as terras agrícolas da invasão urbana, impedir que as cidades vizinhas se unam; preservando o ambiente físico e o caráter especial das cidades históricas; e auxiliar a regeneração urbana, incentivando a reutilização de terras urbanas abandonadas (HOUGH, 2004, p.222 - tradução nossa).

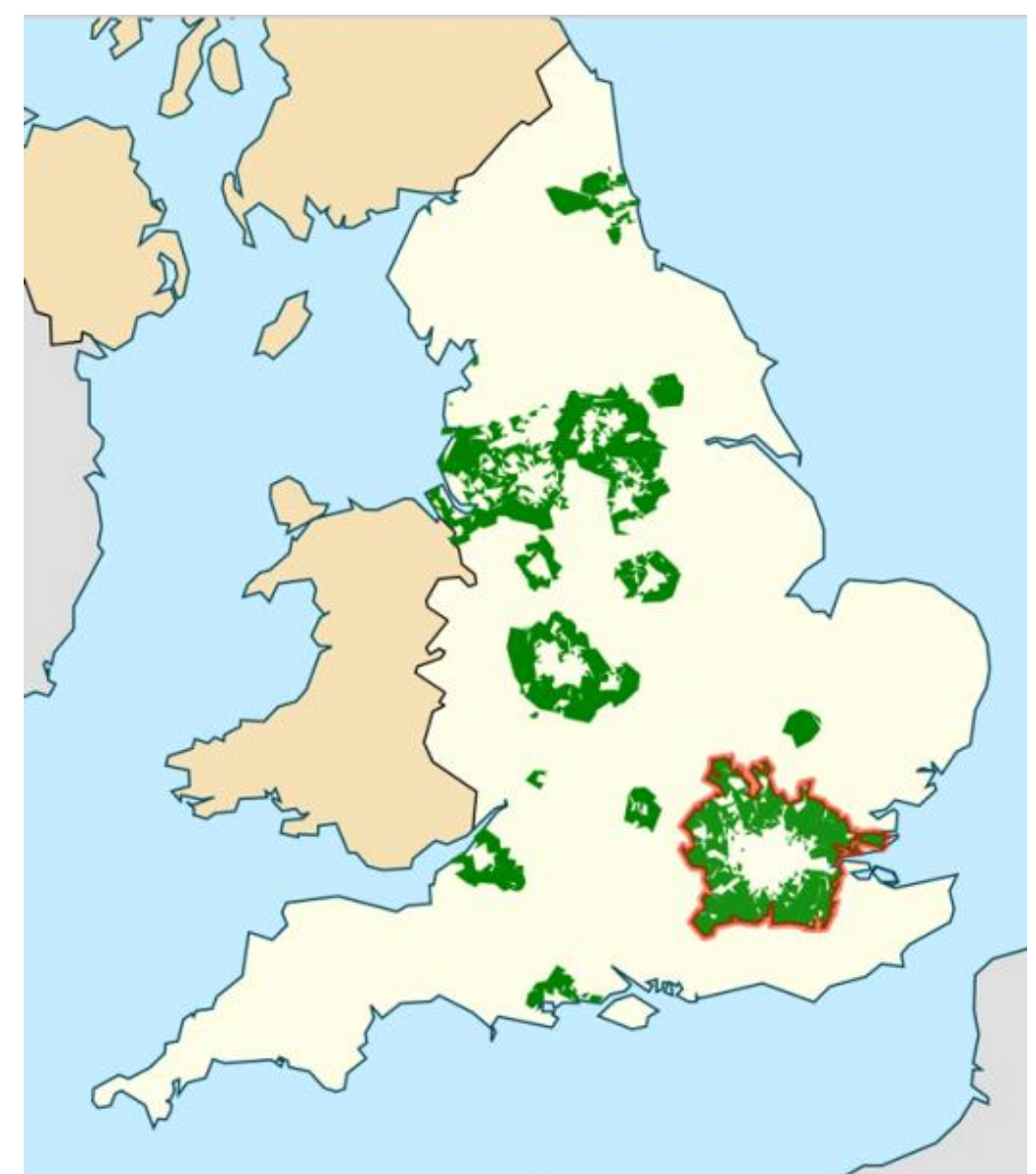

Figura 04 - Cinturões verdes na Inglaterra, em destaque está o cinturão verde da região metropolitana de Londres Disponível em: http://www.urban-hub.com/pt-br/urbanization/cinturoes-verdes-encarecem-ou-melhoram-as-cidades/

A política dos cinturões verdes na atualidade é de nível Nacional, no entanto, é na escala local que as políticas e princípios são implementados. Os benefícios gerados pelo cinturão verde de Londres 
foram inúmeros, sobretudo quando consideramos a questão ambiental em termos de preservação, serviços ecossistêmicos e qualidade de vida. No entanto, ao considerar as questões locais, nota-se que a política dos cinturões são bastantes restritivas e geraram uma série de conflitos e pressões, justamente por limitar o crescimento e desenvolvimento da cidade. De acordo com Michael Hough (2004, p.224) "as políticas do cinturão verde atualmente restringem as oportunidades de formas alternativas de crescimento urbano que possam se ajustar melhor aos princípios do desenvolvimento sustentável." Essas oportunidades alternativas incluem usos ecológicos como áreas de recreação e lazer, áreas de produção de energia sustentável, hortas orgânicas, comunidades e economias diversas, com foco na sustentabilidade.

O cinturão verde de Ottawa, capital canadense, foi proposto no anos de 1949 por Jaques Greber, urbanista francês, fortemente influenciado pelo caso de Londres. Na década de 1990 foi feita uma análise ecológica do cinturão verde de Ottawa, que se desdobrou em uma nova proposta para a área, alterando alguns princípios do plano original. Um dos principais objetivos das modificações do cinturão verde de Ottawa era o de assegurar uma boa relação entre o ambiente construído e o ambiente natural, além de garantir a biodiversidade e mobilidade das espécies. Para tanto, definiuse uma hierarquia, na qual as áreas de grande interesse ambiental e diversidade biológica deveriam ter uma abordagem bastante restritiva, deveria haver uma área envoltória às áreas protegidas que protegesse as mesmas de usos potencialmente poluidores e indevidos, e finalmente a criação de corredores verdes que conectasse as grandes áreas de interesse ambiental e permitindo o trânsito das espécies (HOUGH, 2004).
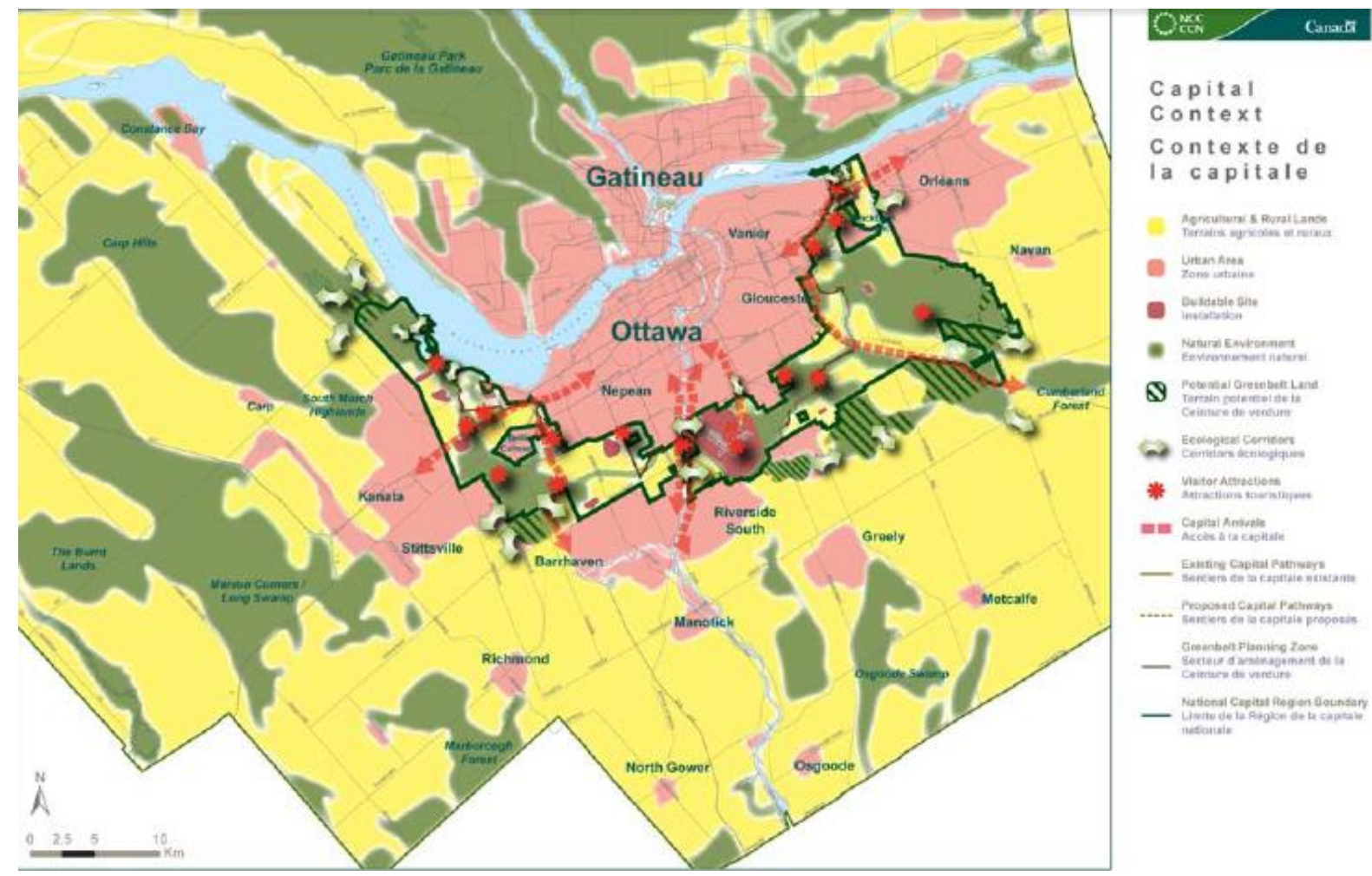

Figura 05 : Cinturão verde de Otawa

Disponível em: http://www.sweetloveable.com/canada-s-national-capital-greenbelt-master-plan-review-publicconsultation-final-phase-feb-19-20-2013/. Acesso: Setembro de 2018

O caso de Ottawa, trabalha um olhar mais apurado do território, propondo diferentes tipos de abordagem ao cinturão e considerando o nível de interesse ambiental da área em questão, diferenciando os tipos de uso em seu território, contando com áreas de uso mais restritivo, áreas 
de turismo com atrações para os visitantes, combinado usos distintos e trabalhando conceitos de conectividade e ecologia da paisagem em seu masterplan.

\section{CONSIDERAÇÕES FINAIS}

As franjas urbano-ambientais da Região Metropolitana de São Paulo possuem um caráter estratégico, sobretudo do ponto de vista ambiental, podendo trazer inúmeros benefícios que passam por qualidade de vida, infraestrutura, melhoria do clima, gestão ambiental e valorização do território. Apesar de seu grande caráter estratégico e a existência de áreas de conservação integral e de uso sustentável trazendo instrumentos que promovem a proteção e conservação dessas áreas, ainda existem muitos desafios a ser vencidos, sobretudo na escala local. É importante que as políticas públicas pensadas para estes importantes remanescentes naturais que envolvem esta grande mancha urbana tragam benefícios e desenvolvimento a nível local e também regional. Para tanto, é necessário que haja um olhar apurado acerca do território, considerando sua vocação, particularidades e envolvendo diferentes agentes em seu processo. É interessante retomar aqui o caso do cinturão verde da Região Metropolitana de Londres, que proporcionou diversos benefícios do ponto de vista ambiental, mas que carece de um olhar mais atento às necessidades locais, sendo menos rígido e promovendo o desenvolvimento sustentável. Vale lembrar que no caso londrino, existe uma governança metropolitana, Greater London Authority (GLA), que promove mediações e executa planos na escala regional. Talvez esse seja um dos grandes desafios da Região Metropolitana de São Paulo, que atualmente discute o Plano de desenvolvimento Urbano Integrado da Metrópole (PDUI), mas não possui uma governança eleita e comprometida com o cumprimento do mesmo. O caso de Ottawa é um grande exemplo de cinturão verde que considera conceitos importantes que proporciona benefícios locais e regionais a partir de um olhar mais apurado do território, considerado diferentes usos e níveis de restrição. Existe um campo aberto de estudos a ser explorado acerca dos desafios e possibilidades das dimensões da sustentabilidade nas franjas urbano-ambiental da Região Metropolitana.

\section{REFERÊNCIAS}

ACSELRAD, Henri. Justiça Ambiental: ação coletiva e estratégias argumentativas. In:

ACSELRAD, Henri; HERCULANO, Selene; PÁDUA, José Augusto (org.). Justiça Ambiental e Cidadania. Rio de Janeiro: Relume Dumará; Fundação Ford, 2004.

ALVIM, Angélica T.B. A Contribuição do Comitê da Bacia do Alto do Tietê à Gestão da Bacia Metropolitana,1994-2001. São Paulo, 2003. Tese (Doutorado) - Programa de Pós-Graduação em Arquitetura e Urbanismo, Universidade de São Paulo (FAUUSP)

ALVIM, Angelica; MARQUES, Andresa; ALVES, Karina. Urbanização e Meio Ambiente no Contexto das Franjas Metropolitanas De São Paulo: O Caso das Sub-bacias Juqueri-Cantareira e Billings. Salvador, 2018.

BRYANT, C.R. et. al. The city's countryside: land and its management in the rural urban fringe, Longman, New york. 1982 
FARR, Douglas. Urbanismo sustentável: desenho urbano com a natureza. Porto Alegre Bookman 2013. 304p.

IBGE. Censo Demográfico 2010. Rio de Janeiro, IBGE, 2010.

IBGE. Classicação e caracterização dos espaços rurais e urbanos do Brasil : uma primeira aproximação. Rio de Janeiro, IBGE - Coordenação de Geografia, 2017

LEITE, Carlos; AWAD, Juliana di Cesare Marques. Cidades sustentáveis, cidades inteligentes: desenvolvimento sustentável num planeta urbano. Porto Alegre: Bookman, 2012.

LEITE, Julia R. A paisagem entre a cidade e a natureza: a reserva da biosfera de São Paulo. In PELLEGRINO, Paulo; MOURA, Newton B.(org) Estratégias para uma infraestrutura verde. Barueri-SP: Manole, 2017. 79-100p

LOMBARDO, M. A.; QUEVEDO NETO, P. S. Transformação da paisagem na área de transição urbano-rural: repercussões sobre o clima urbano. In: Encontro Nacional sobre o conforto no ambiente construído. São Pedro: ANTAC, 2001.

LUCCHESE, M. C. O planejamento urbano de Londres (1943 - 1947). Risco: Revista de Pesquisa em Arquitetura e Urbanismo (Online), n. 15, p. 67-81, 1 jan. 2012.

MAGNAGHI, A. The Urban Village: A charter for democracy and local self-sustainable development. Chicago. ZED Books. 2005. 240p.

ONU. World Urbanization Prospects: The 2018 Revision. 2018. Disponível em: < https://esa.un.org/unpd/wup/Publications/Files/WUP2018-KeyFacts.pdf >. Acesso em: 07 jul. 2018.

PELLEGRINO, P.R.M., GUEDES, P.P., PIRILLO, F.C., FERNANDES, S.A. A paisagem da borda: uma estratégia para condução das águas, da biodiversidade e das pessoas. In: COSTA, L.M.S.A. (org.) Rios e Paisagens Urbanas em cidades brasileiras. Rio de Janeiro: Viana \& Mosley: Ed. PROURB, p.57 -76

QUEVEDO NETO, P.S.; LOMBARDO, M. A. Dinâmica e Qualidade da Paisagem na Área de Transição urbano-rural. In: Encontro de Geógrafos da América Latina, 10., 2005, São Paulo: Departamento de Geografia/ FFLCH/USP, 2005, p.12158-12173

ROCHA, Jorge; TENEDÓRIO, José; SOUSA, Paulo M.; COSTA, Eduardo M.; COSTA, Nuno M. Caracterização da franja urbana-rural através de gradientes: análise por continuum versus contraste. 2005.

https://www.researchgate.net/publication/237677356_caracterizacao_da_franja_urbanarural_atraves_de_gradientes_analise_por_continuum_versus_contraste/citations. Acesso em: $29 / 05 / 2018$

RODRIGUES, E. A.; MORAES VICTOR, R. A. B.; CAMACHO PIRES, B.C. A Reserva Da Biosfera Do Cinturão Verde Da Cidade De São Paulo Como Marco Para A Gestão Integrada Da 
Cidade, Seus Serviços Ambientais E O Bem-estar Humano. São Paulo em Perspectiva, v. 20, n. 2, p. 71-89, abr./jun. 2006

SCOTT, Alister et al. Disintegrated development at the rural-urban fringe: Re-connecting spatial planning theory and practice. Progress in Planning. London, v. 83, p.1-52, 2013. 